CAKRAWALA - Repositori IMWI | Volume 4, Nomor 2, Oktober 2021

p-ISSN: 2620-8490; e-ISSN: 2620-8814

\title{
PENGARUH KEPEMILIKAN INSTITUSIONAL ASING DAN KINERJA KEUANGAN TERHADAP HARGA SAHAM
}

\author{
Zulkarnain Zulkarnain \\ Program Studi Akuntansi, Institut Manajemen Wiyata Indonesia \\ zulkarnain@imwi.ac.id \\ Siti Mariyam \\ Program Studi Akuntansi, Institut Manajemen Wiyata Indonesia \\ siti.mariyam123.sm@gmail.com
}

\begin{abstract}
Abstrak
Kajian ini dimaksudkan guna menyelidiki pengaruh kepemilikan institusional asing dan ke mampu an finansial yang diproksikan atas Return on Equity (ROE) atas harga saham. kajian di Bursa Efek Indonesia periode 2012 -2016. Sampel kajian ditetapkan atas memakai teknik purposive sampling dan didapatkan sampel sebanyak 11 perseroan atas 55 pengamatan. Teknik analisis data memakai analisis regresi berganda dan menggunakan alat bantu SPSS versi 20. Hasil kajian memperlihatkan bahwa kepemilikan institusional asing berpengaruh positif atas harga saham. Keberadaan investor asing dianggap mampu memberikan andil melalui strategi dan metode untuk meningkatkan nilai perseroan. ROE juga ditemukan berpengaruh positif atas harga saham. Return yang baik mampu menarik perhatian investor. Ketertarikan investor atas permintaan untuk bergabung yang semakin besar mampu meningkatkan harga saham.
\end{abstract}

Kata Kunci: kepemilikan institusional asing, ROE, harga saham.

\begin{abstract}
This study is intended to investigate the effect of foreign institutional ownership and financial capability as proxied by Return on Equity (ROE) on stock prices. study on the Indonesia Stock Exchange for the period 2012-2016. The study sample was determined using purposive sampling technique and obtained a sample of 11 companies with 55 observations. The data analysis technique uses multiple regression analysis and uses the SPSS version 20 tool. The results of the study show that foreign institutional ownership has a positive effect on stock prices. The presence of foreign investors is considered capable of contributing through strategies and methods to increase the value of the company. ROE was also found to have a positive effect on stock prices. A good return can attract the attention of investors. The interest of investors with the growing demand to join can increase the share price.
\end{abstract}

Keywords: foreign institutional ownership, ROE, stock prices 


\section{PENDAHULUAN}

Pasar modal mendapat posisi ekonomi yang cukup penting pada pembangunan nasional sebagai salah satu sumber pembiayaan bagi dunia usaha dan wahana investasi bagi masyarakat yang memanfaatkannya (OJK, 2020). Pasar modal menyediakan tempat pertemuan antara yang menawarkan modal atas yang memerlukan dana, baik dalam jangka menengah maupun jangka panjang yang melebihi satu tahun. Pasar modal mampu pula memberikan fungsi keuangan karena mampu memberikan peluang guna mendapatkan keuntungan atau return bagi pemilik dana sesuai karakteristik investasi yang dimiliki pasar modal (Fakhruddin, 2011).

Banyak yang menginventasikan sebagian atau bahkan seluruh dananya di pasar modal atas maksud guna mendapatkan profit di masa depan (Fahmi, 2013). Pasar modal mampu merefleksikan kondisi pertumbuhan ekonomi. Semakin baik pergerakan pasar modal maka akan memberikan pengaruh positif terhadap pertumbuhan bangsa. Berbagai instrumen keuangan ditawarkan seperti saham, obligasi, ekuitas, instrumen derivatif dan instrumen lainnya.

Saham merupakan suatu item keuangan di pasar modal yang menjadi primadona di mata investor yang menyukai capital gain (Sulistyastuti, 2002). Hal tersebut dikarenakan saham mampu memberikan keuntungan jangka pendek dari selisih harga jual dan harga beli harian saham. Hasil dari capital gain ini bahkan bisa lebih tinggi dibanding atas membangun sebuah usaha.

Banyak faktor yang mampu memengaruhi harga saham. Selain dari hukum ekonomi yaitu hukum permintaan dan penawaran, terdapat beberapa faktor yang bisa memengaruhi harga saham. Faktor tersebut diantaranya adalah faktor teknikal dan faktor fundamental.

Analisis teknikal mampu dilakukan atas memperkirakan harga saham dari hasil pengamatan yang terjadi pada pasar modal yang diindikasikan atas perubahan harga saham pada tempo lalu. Investor mampu memutuskan kapan harus membeli, menjual, atau menjaga saham-sahamnya atas memakai indikator-indikator teknis atau memakai analisis grafik. Guna memutuskan nilai saham pada analisis teknikal ini memakai data dari pasar, seperti harga dan volume transaksi penjualan saham.

Faktor kedua dalam memilih harga saham adalah atas faktor fundamental. Jika faktor teknikal memperhatikan secara grafik, di dalam faktor fundamental, harga saham di masa depan diperkirakan atas mengestimasikan nilai faktor-faktor fundamental di masa yang akan datang, dan menetapkan taksiran harga saham atas menghubungkan variabel-variabel tersebut. Adapun variabel dalam faktor fundamental diantaranya adalah faktor yang berkaitan erat atas keadaan perseroan seperti keadaan manajemen organisasi sumber daya manusia dan keadaan finansial perseroan yang tercermin pada ke mampu an finansial.

Analisis fundamental memfokuskan pada rasio keuangan dan peristiwaperistiwa yang terjadi langsung maupun tidak langsung memengaruhi ke mampu an finansial perseroan. Faktor fundamental lebih cocok dipakai untuk investasi jangka panjang. Beberapa faktor fundamental yang memengaruhi harga saham diantaranya: penjualan, peningkatan penjualan, operasional perseroan, laba, dividen, mata uang, kepemilikan 
institusional, kepemilikan manajerial, dan lain sebagainya.

Faktor-faktor fundamental tersebut mampu direfleksikan dari report keuangan. Laporan laba rugi menjadi suatu laporan keuangan yang memiliki fungsi untuk menyampaikan kinerja perseroan untuk menghasilkan laba. Pencapaian sebuah tujuan perseroan dicerminkan dalam besar kecilnya laba perseroan yang diraih. Laba menjadi salah satu puncak keputusan investor dalam bahan pertimbangan untuk memutuskan pilihan dalam berinvestasi, termasuk membeli atau menjual suatu instrumen keuangan/investasi.

Selain laba, struktur kepemilikan, dalam hal ini kepemilikan institusional mampu menjadi faktor perubahan harga saham. Keberadaan kepemilikan institusional asing dianggap mampu berpengaruh dalam menggerakkan roda kemajuan suatu perseroan. Strategi dalam menjalankan perseroan mampu diadopsi dari pihak asing yang berasal dari negara maju. Pihak luar tersebut mampu menjadi pihak yang berpengaruh dalam pembuatan keputusan. Strategi bisnis pihak asing dianggap lebih mumpuni dalam menghasilkan laba yang optimal.

Menurut Raharjanti \& Setyowati (2017) kepemilikan institusional penting dalam manajemen pengawasan dan mendorong pengawasan yang lebih bagus. Semakin bagus monitoring yang dilakukan, maka akan semakin baik pula ke mampu an perseroan untuk mengoptimalkan kemakmuran pemegang saham. Hal tersebut sejalan atas pendapat Fauzan \& Nadirsyah (2012) yang menjabarkan bahwa kepemilikan institusional mempunyai pengaruh atas nilai perusahan. Nilai perseroan digambarkan melalui harga saham. Kajian ini bertujuan guna kembali menilai pengaruh kepemilikan institusional asing dan kinerja keuangan atas harga saham.

\section{TINJAUAN PUSTAKA \\ Harga Saham}

Harga saham adalah harga yang terjadi di pasar modal oleh pelaku pasar pada waktu tertentu, dan diputuskan oleh penawaran dan permintaan pelaku pasar. Jenis harga saham mampu terdiri dari harga nominal, harga perdana, dan harga pasar (Widoatmojo, 2017). Harga nominal adalah harga yang tertera dalam saham yang dikeluarkan oleh emiten guna mengukur setiap saham yang keluar. Harga perdana adalah harga yang tertera di bursa. Harga perdana diputuskan oleh emiten dan emisi. Harga perdana berlaku bagi investor yang membeli saham pada saat penawaran umum. Harga pasar adalah harga jual dari investor yang satu atas investor yang lain. Harga ini berlaku ketika saham telah dicatat di bursa efek.

Analisis fundamental bisa memperkirakan harga saham atas mengestimasikan nilai faktor-faktor fundamental seperti keadaan manajemen, organisasi, sumber daya manusia, dan keuangan. Analisis fundamental memfokuskan pada ke mampu an perseroan yang mengeluarkan saham dan analisis ekonomi yang akan memengaruhi masa depan perseroan. Faktor-faktor fundamental tersebut diantaranya: Penjualan, Pertumbuhan penjualan, Operasional perseroan, Laba, Dividen, Rapat Umum Pemegang Saham (RUPS), Perubahan manajemen, dan Pernyataanpernyataan yang dikeluarkan oleh manajemen perseroan (Widoatmojo, 2017).

\section{Struktur Kepemilikan Institusional}


Struktur kepemilikan institusi ialah tingkat kepemilikan saham perseroan yang dimiliki oleh institusi atau lembaga (Hery, 2014). Kepemilikan institusional mampu memberikan mekanisme pengawasan dalam perseroan. Institusi yang dituju dalam kepemilikan institusi adalah perseroan investasi, bank, perseroan asuransi maupun kepemilikan lembaga dan perseroan lain. Kepemilikan Institusional dibagi ke dalam dua jenis yakni Kepemilikan Institusional Domestik dan Kepemilikan Institusional Asing.

Perseroan mampu dikatakan memiliki struktur kepemilikan domestik jika kepemilikan institusional di perseroan tersebut lebih dominan orang lokal yang menjabatnya. Sedangkan untuk kepemilikan publik, kepemilikan tersebut dimiliki oleh masyarakat umum. Kepemilikan domestik memiliki pengaruh yang besar, karena mampu memengaruhi perseroan melalui media masa. Kepemilikan institusional asing merupakan kepemilikan yang para pemangku keputusan dominan berasal dari luar negeri. Kepemilikan asing mampu menjadi faktor pemicu dalam pengungkapan tanggung jawab sosial. Terutama kepemilikan asing yang berasal dari Eropa dan Amerika Serikat (Hery, 2014). Hal serupa lainnya, atas adanya kepemilikan asing pada perseroan maka perseroan akan ditekankan untuk memberikan informasi yang beragam. Sehingga perseroan lebih terarahkan ke metode dan budaya asing yang mampu memotivasi perseroan untuk menjadi lebih baik.

\section{Kepemilikan Institusional Asing dan Harga Saham}

Kepemilikan institusional asing merupakan proporsi kepemilikan dari badan, institusi, atau individu yang berstatus luar negeri atau bukan berasal dari Indonesia terhadap seluruh kepemilikan perseroan. Institusi asing diklaim mampu membangun strategi, sudut pandang, dan ide dari luar negeri, dalam hal ini negara maju, untuk mampu meningkatkan nilai perseroan (Polovina \& Peasnell, 2015). Institusi asing melalui pola pengawasan yang dilakukan dianggap mampu menekan perseroan bekerja lebih baik sehingga mampu mendongkrak pertumbuhan dan nilai perseroan lebih baik (Bremholm, 2015). Nilai perseroan diproksikan melalui harga saham. Atas dasar ini, diajukan hipotesis pertama:

$\mathrm{Ha}_{1}$ : Kepemilikan institusional asing berdampak positif atas harga saham.

\section{Kinerja Keuangan dan Harga Saham}

Ke mampu an keuangan dalam kajian ini diproksikan atas Return on Equity (ROE). ROE disebut juga sebagai laba atas ekuitas, yang seringkali dijadikan patokan investor dalam menentukan langkahnya. Melalui ROE mampu dikaji ke mampu an perseroan tentang sampai mana usaha perseroan menggunakan sumber daya yang dimiliki dalam menyediakan laba atas ekuitas (Fahmi, 2015). Semakin tinggi ROE memperlihatkan bahwa perseroan semakin efektif dalam memanfaatkan ekuitas guna mendapatkan laba bersih setelah pajak. Atas demikian, semakin tinggi ROE, ke mampu an perseroan terus meningkat. Hal ini kemudian tentu menumbuhkan magnet bagi investor terhadap perseroan. Hal ini akan berpengaruh pada harga saham dari perseroan di pasar modal yang akan terus tumbuh, alhasil ROE akan berdampak pada harga saham perseroan. Atas dasar ini, diajukan hipotesis kedua: 
$\mathrm{Ha}_{2}$ : ROE berpengaruh positif terhadap harga saham.

\section{METODE PENELITIAN}

Kajian ini tergolong dalam jenis penelitian asosiasi kuantitatif. Tipe data yang dipakai adalah data bantu. Data tersebut berasal dari report keuangan tahunan perseroan yang telah diaudit untuk tahun pelaporan 2012-2016 dan dipublikasikan di Bursa Efek Indonesia, yang tersedia melalui situs resmi http://www.idx.co.id. Data yang dipakai mencakup data ekuitas, laba bersih setelah pajak, informasi saham dan informasi kepemilikan saham.

\section{Populasi dan Sampel}

Populasi pada kajian ini adalah seluruh perseroan publik yang tertera di Bursa Efek Indonesia sektor industri barang konsumsi periode tahun 2012-2016. Sektor tersebut merupakan sektor yang selalu dibutuhkan oleh masyarakat dari bangun tidur sampai tidur kembali. Pemilihan sampel dilaksanakan bersumber dari metode purposive sampling, yaitu pemilihan sampel secara teratur atas mengamati persyaratan tertentu guna membuahkan sampel yang representatif sesuai atas persyaratan yang ditetapkan (Sekaran \& Bougie, 2016). Kriteria atau pertimbangan purposive sampling dalam kajian ini yaitu:

1. Data perseroan selama tahun penelitian selalu mempublikasikan laporan tahunan.

2. Data yang tersaji dalam laporan keuangan memiliki variabel yang diteliti secara lengkap.

3. Laporan keuangan yang dipublikasikan merupakan laporan yang telah diaudit dan dipublikasikan pada akhir tahun periode.

\section{Operasionalisasi Variabel}

Operasionalisasi variabel diperlukan guna memutuskan jenis dan indikator dari variabel-variabel sehubungan atas kajian ini. Variabel dalam penelitian ini terbagi menjadi dua yaitu variabel bebas (independent variable) dan variabel terikat (dependent variable). Variabel bebas yaitu kepemilikan institusional asing dan ke mampu an keuangan, sedangkan variabel terikat yaitu harga saham.

Kepemilikan asing dinilai atas jumlah presentase saham yang dikuasai institusi asing atau yang bukan institusi Indonesia berbanding atas seluruh jumlah saham suatu entitas yang bersumber dari Indonesia. Ke mampu an finansial diukur atas return on equity (ROE). ROE dimaknai juga sebagai laba atas ekuitas, yang seringkali dijadikan patokan investor dalam menentukan langkahnya. Hal ini bisa diketahui melalui laporan keuangan yang selalu menyajikan rasio ini di laporan tahunan. Melalui ROE mampu dikaji ke mampu an perseroan tentang sejauh mana usaha perseroan memakai sumber daya yang ada guna menyediakan laba atas ekuitas (Fahmi, 2015).

Harga saham yang dipakai pada kajian ini adalah harga penutupan atau closing price pada akhir tahun berjalan selama pengamatan dilakukan. Harga saham dibentuk berdasarkan demand and supply di pasar modal yang biasanya disebut harga penutupan.

\section{Teknik Analisis Data}

Setelah mengumpulkan data, tahap berikutnya adalah menganalisis. Metode analisis dilakukan atas pendekatan pengolah data memakai metode statistik atau matematik yang terkumpul dari data sekunder, agar penelitian memiliki hasil 
yang baik dan memiliki kadar kualitas yang memadai. Cara menentukan alat ukur yang baik mampu memberikan hasil terbaik. Alat ukur tersebut merupakan statistik deskriptif dan uji asumsi klasik.

Uji hipotesis memakai regresi yang mencakup lebih dari satu variabel bebas yang biasa disebut regresi berganda (multiple regression). Adanya ulasan ini dimaksudkan agar mampu memperkirakan nilai variabel dependen menurut satu atau lebih variabel bebas.

\section{HASIL}

\section{Hasil Statistik Deskriptif}

Selama rentang periode penelitian, terdapat populasi 35 perseroan atas 165 laporan keuangan. Perseroan-perseroan tersebut merupakan perseroan yang bersumber dari bidang industri barang konsumsi yang memiliki lima subsektor. Kelima subsektor tersebut adalah makanan dan minuman, industri rokok, obat-obatan, kosmetik, dan perlengkapan rumah tangga. Dari 165 laporan keuangan terdapat 55 laporan keuangan yang telah memenuhi kriteria dari purposive sampling.

Laporan keuangan tersebut berasal dari 11 perseroan salah satu diantaranya yaitu Akasha Wira International Tbk. Sebanyak 105 laporan keuangan yang berasal dari 21 perseroan tidak memenuhi kriteria. Perseroan-perseroan tersebut cenderung tidak terdapat investor yang berasal dari institusi asing. Berikut ini disajikan tabel deskriptif statistik variabel kepemilikan institusional asing, ROE, dan harga saham:

Tabel 1. Hasil Statistik Deskriptif

\begin{tabular}{llrrrr}
\hline & N & \multicolumn{1}{l}{ Min } & \multicolumn{1}{c}{ Max } & \multicolumn{1}{c}{ Mean } & \multicolumn{1}{c}{ Std. Dev. } \\
\hline Kep. Institusi Asing & 55 & 9,08 & 92,66 & 59,89 & 24,26 \\
ROE & 55 & $-0,03$ & 0,98 & 0,26 & 0,27 \\
Harga Saham & 55 & 112,00 & $6.900,00$ & 952,54 & $1.032,48$ \\
\hline
\end{tabular}

Sumber: Hasil Olah Data (2021)

Tabel 1 menampilkan nilai terendah kepemilikan institusional asing di 9,08\% dan tertinggi di 92,66\%. Nilai terendah sebesar 9,08\% dikuasai oleh PT Tiga Pilar Sejahtera Food Tbk pada 2013, dan nilai tertinggi sebanyak 92,66\% yang dikuasai oleh PT Darya-Varia Laboratoria Tbk. PT Darya-Varia Laboratoria Tbk. memiliki persentase tersebut selama empat tahun atas nilai yang sama yakni pada tahun 2012 sampai tahun 2015. Di tahun 2016 persentase kepemilikan institusional asing menurun 0,53 persen. Nilai rata-rata selama lima tahun penelitian adalah sebesar 59,42. Hal tersebut mampu diindikasikan bahwa kecenderungan perseroan di Indonesia khususnya perseroan yang termasuk pada golongan industri barang konsumsi dimiliki oleh institusi asing.

Dilihat dari persentase kepemilikan institusional asing yang nilainya kurang dari $50 \%$ adalah 5 perseroan dari 14 perseroan, diantaranya PT Wismilak Inti Makmur Tbk, PT Kedaung Indah Can Tbk, PT Parasidha Aneka Niaga Tbk, PT Nippon Indosari Corporindo Tbk, dan PT Prydam Farma Tbk. Sembilan perseroan lainnya memiliki persentase kepemilikan lebih dari nilai rata-rata. Nilai standar deviasi pada kepemilikian institusional asing adalah sebesar $24,27 \%$. Nilai standar deviasi tersebut tergolong baik karena nilai 
tersebut lebih rendah dari nilai average kepemilikan institusional asing.

Selanjutnya, tabel 1 menunjukkan nilai terendah dan nilai tertinggi ROE yang tiap tiap sebanyak $-0,03$ dan 0,98 . Nilai tersebut masing-masing dimiliki oleh PT Langgeng Makmur Industri Tbk dan PT Nippon Indosari Corporindo Tbk. Nilai rata-rata ROE sebesar 0,26 dan penyimpangan data ROE di 0,27 , yang hal ini berarti cukup baik karena penyimpangan tersebut tidak terlalu jauh dari nilai rata-rata.

Di lihat dari harga saham yang terefleksikan dari harga penutupan di BEI selama tahun penelitian terdapat nilai minimal sebesar Rp 112,- dan nilai maksimal sebesar Rp 6.900,-. Masingmasing data tersebut dimiliki secara berurutan oleh PT Prydam Farma Tbk dan PT Nippon Indosari Corporindo Tbk. Rata-rata harga saham selama lima tahun adalah Rp 952,54,-. Dari kesebelas perseroan ada enam perseroan yang mempunyai harga saham di bawah ratarata. Kelima perseroan tersebut adalah PT Suka Laut Tbk, PT Wismilak Inti Makmur Tbk, PT Prydam Farma Tbk, PT Kedaung
Indah Tbk dan PT Langgeng Makmur Industri Tbk. Standar deviasi dari harga saham sebesar Rp 1.032,48. Antara average atas standar deviasi memiliki nilai data yang tidak terlalu jauh senilai $\mathrm{Rp}$ 79,94. Hal tersebut menunjukan bahwa sebaran data harga saham dinilai baik.

\section{Hasil Uji Asumsi Klasik}

Serangkaian uji asumsi klasik dilakukan, yang meliputi uji normalitas, uji heteroskedastisitas, uji autokorelasi, dan uji multikolineritas. Dari hasil uji kolmogorov-smirnov diperoleh hasil model regresi memiliki distribusi yang normal. Uji heteroskedastisitas menemukan tidak terjadi heteroskedastisitas. Uji autokorelasi menemukan tidak terdapat autokorelasi. Dan uji multikolineritas pada data dari 55 perseroan diperoleh bahwa antar variabel tidak ditemukan korelasi dan data ini termasuk baik karena tidak terjadi korelasi.

\section{Hasil Uji Hipotesis}

Tabel 2 dibawah menyajikan hasil penilaian hipotesis memakai analisis regresi berganda:

Tabel 2. Hasil Uji Regresi Berganda

\begin{tabular}{lrrr}
\hline Variabel & Coefficient & t-Statistic & \multicolumn{1}{l}{ Sig. } \\
\hline Intercept & 148,605 & 0.424 & \\
Kep. Institusi Asing & 12,928 & 2,468 & 0,017 \\
ROE & $1.258,746$ & 2,670 & 0,010 \\
Observations & & 55 & \\
Adjusted R & & 0,093 & \\
F-statistic & & 7,223 & 0,002 \\
\hline
\end{tabular}

Sumber: Hasil Olah Data (2021) 
Tabel 2 memperlihatkan bahwa nilai $\mathrm{t}$ hitung dari kepemilikan institusi asing yaitu sebanyak 2,468 atas nilai signifikansi sebanyak 0,017. Sementara itu, nilai t tabel adalah sebanyak 2,306. Maka mampu ditulis atas $\mathrm{t}$ hitung $>\mathrm{t}$ tabel atau 2,468 $>2,306$, dan penting $0,017<0,050$. Hasil ini mendapat hipotesis pertama bahwa kepemilikan institusional asing berdampak atas harga saham. Arah pengaruh yang ditunjukkan adalah positif.

Tabel 2 juga menunjukkan nilai $t$ hitung dari ROE sebanyak 2,670 atas nilai signifikansi sebanyak 0,010. Sedangkan nilai $\mathrm{t}$ tabel adalah sebanyak 2,306. Maka mampu ditulis atas $\mathrm{t}$ hitung $>\mathrm{t}$ tabel atau $2,670>2,306$, dan signifikansi $0,010<$ 0,050 . Hasil ini pun mendapat hipotesis kedua bahwa ROE berdampak atas harga saham. Arah dampak yang ditunjukkan juga positif.

Selanjutnya tabel 2 menunjukkan hasil uji $\mathrm{F}$ atas nilai $\mathrm{F}$ hitung sebanyak 7,223, lebih besar dari $\mathrm{F}$ tabel sebanyak 3,180. Nilai signifikansi dari uji $\mathrm{F}$ adalah sebesar 0,002 . Nilai itu lebih rendah dari 0,050 . Hasil ini menerima hipotesis bahwa kepemilikan institusional asing dan ROE berdampak atas harga saham. Arah pengaruh yang ditunjukkan adalah positif.

Selanjutnya nilai Adjusted $R$ Square ditunjukkan sebesar 0,093 atau 9,3\%. Hasil ini bisa disimpulkan sebagai ke mampu an variabel kepemilikan institusional asing dan ROE secara seksama menjelaskan variasi harga saham sebesar 9,3\% dan sisanya sebesar $90,7 \%$ dijelaskan oleh variabelvariabel lain di luar penelitian ini.

\section{PEMBAHASAN}

Pengaruh Kepemilikan Institusional Asing terhadap Harga Saham

Hasil statistik (uji t) dari penelitian ini menunjukkan bahwa kepemilikan institusional asing berpengaruh positif terhadap harga saham. Bisa diketahui dari $\mathrm{t}$ hitung yang lebih besar dari $t$ tabel yakni 2,468 > 2,306, dan nilai signifikansi 0,017 lebih kecil dari 0,050. Hasil ini menunjukkan bahwa investor asing bisa memberikan pengaruh yang baik terhadap nilai perseroan.

Investor asing mampu menjadi pihak ketiga antara pihak manajemen dan pemilik perseroan dalam konflik keagenan. Investor asing pun turut ambil andil dalam keputusan perseroan baik dari segi perencanaan strategi maupun pengembangan metode perseroan yang bersifat krusial. Hal tersebut mampu membuat ke mampu an perseroan makin maju. Kemempuan perseroan yang terus maju akan menyebabkan investor tertarik. Ketertarikan investor terhadap prospek perseroan yang baik akan meningkatkan harga saham. kajian ini diperkuat oleh penelitian Kapoor \& Sachan (2015) yang hasil penelitiannya menyatakan bahwa kepemilikan institusional asing mempunyai dampak atas tren harga saham.

\section{Pengaruh ROE terhadap Harga Saham}

Hasil statistik (uji t) dari kajian ini juga memperlihatkan bahwa ROE berdampak baik atas harga saham. mampu dilihat dari $\mathrm{t}$ hitung yang lebih besar dari $t$ tabel yakni 2,670 > 2,306, dan nilai signifikansi 0,010 lebih kecil dari 0,050. Hasil ini memperlihatkan bahwa ROE yang tinggi mampu memberikan pengaruh pada tingginya nilai perseroan.

Meningkatnya pendapatan atau return perseroan melalui maksimalisasi modal akan menarik perhatian investor. Sejalan atas hukum ekonomi yaitu penawaran dan permintaan. Semakin banyak perseroan yang tertarik maka permintaan untuk bergabung semakin besar. Hal tersebut mampu memajukan harga saham. Hasil ini sejajar 
atas kajian Barakat (2014) yang berpendapat bahwa ROE mempunyai dampak yang penting atas harga saham. Hal ini diperkuat oleh penelitian Ningrum \& Suzan (2015) yang berpendapat bahwa ROE mempunyai dampak atas harga saham.

\section{Pengaruh Kepemilikan Institusional Asing dan ROE terhadap Harga Saham}

Hasil statistik (uji F) dari kajian ini juga memperlihatkan bahwa kepemilikan institusional asing dan ROE secara seksama berdampak baik atas harga saham. mampu dilihat dari $\mathrm{F}$ hitung yang lebih besar dari $\mathrm{F}$ tabel yakni $7,223>3,180$, dan nilai signifikansi 0,002 lebih kecil dari 0,050.

Hasil ini memberikan gambaran adanya peran dari institusional asing untuk mampu membantu pertumbuhan ekonomi Indonesia. Tidak mampu kita pungkiri bahwa atas adanya investor asing mampu membantu perekonomian Indonesia yang notabenenya investor asing itu berasal dari negara maju. Negara yang sudah maju disinyalir memiliki lebih banyak metode yang mampu ditularkan seperti pemikiran, teknologi dan berbagai prinsip dalam upaya peningkatan kesejahteraan bangsa. Serta ROE mampu dijadikan alat analisis dalam melakukan pertimbangan dalam mencapai keputusan dalam berinvestasi. Atas adanya ROE perseroan mampu menjadikan acuan agar bisa terus memperbaiki kinerja perseroan dalam menghasilkan laba setelah pajak, dan memaksimalkan ekuitas.

\section{Simpulan}

Kajian ini mengkaji dampak kepemilikan institusi asing dan kinerja keuangan yang diwakili oleh ROA atas harga saham perseroan aspek barang konsumsi yang terdaftar di Bursa Efek Indonesia selama periode 2012-2016. Jumlah perseroan yang melengkapi persyaratan sampling adalah 11 perseroan atas total 55 observasi. Analisis data dijalankan atas memakai uji regresi linier berganda alat bantu program SPSS. Menurut pengujian hipotesis dan analisis yang dilakukan, maka ditarik kesimpulan sebagai berikut:

a. Secara parsial variabel kepemilikan institusional asing berpengaruh positif atas harga saham. Keberadaan investor asing dianggap mampu memberikan andil dalam keputusan perseroan, baik dari segi perencanaan strategi maupun pengembangan metode perseroan yang bersifat krusial meningkatkan nilai perseroan.

b. Secara parsial variabel ROE berdampak baik pada harga saham. Meningkatnya return melalui maksimalisasi modal akan menarik perhatian investor. Ketertarikan investor atas permintaan untuk bergabung yang semakin besar mampu meningkatkan harga saham.

c. Secara bersama-sama variabel kepemilikan institusional asing dan ROE berdampak baik pada harga saham. Ke mampu an variabel kepemilikan institusional asing dan ROE secara bersama-sama menjelaskan variasi harga saham ditunjukkan oleh nilai koefisien determinasi atau Adjusted $R$ Square sebesar $9,3 \%$ dan sisanya sebesar $90,7 \%$ dijelaskan oleh variabelvariabel lain di luar penelitian ini.

\section{Keterbatasan dan Saran}

Dalam kajian ini terdapat beberapa keterbatasan pada tidak lengkapnya rasio keuangan yang dipergunakan dalam penelitian; tidak menganalisis faktor internal dan faktor eksternal sehingga hasil tidak lebih spesifik; dan koefisien determinasi 
yang kurang dari 50\% sehingga harga saham lebih banyak terpengaruh oleh faktor lain.

Melalui keterbatasan tersebut disarankan pada penelitian selanjutnya menggunakan rasio keuangan yang lengkap agar hasil penelitian mampu disimpulkan secara lebih komprehensif; mampu menganalisis faktor internal dan faktor eksternal sehingga hasil penelitian mampu lebih spesifik; dan mampu menguji faktor-faktor lain yang memengaruhi harga saham.

\section{Daftar Pustaka}

Barakat, A. (2014). The impact of financial structure, financial leverage and profitability on industrial companies shares value (applied study on a sample of Saudi industrial companies). Research Journal of Finance and Accounting, 5(1), 55-66.

Bremholm, A. (2015). Foreign ownership and foreign directors-the effects on firm performance in Japan.

Fahmi, I. (2013). Ekonomi Politik Teori dan Realita. Alfabeta.

Fahmi, I. (2015). Analisis Laporan Keuangan. Alfabeta.

Fakhruddin, D. D. (2011). Pasar Modal di Indonesia Edisi 3. Salemba Empat.

Fauzan, F., \& Nadirsyah, M. A. (2012). Pengaruh Struktur Kepemilikan dan Kinerja Keuangan Early Warning System Terhadap Nilai Perusahaan (Studi Pada Perusahaan Asuransi Yang Terdaftar di Bursa Efek Indonesia). Jurnal Akuntansi ISSN, 2302, 164.

Hery, S. (2014). Controllership: Knowledge and Management Approach. Grasindo.

Kapoor, S., \& Sachan, R. (2015). Impact of FDI \& FII on Indian stock markets. International Journal of Research in
Finance and Marketing, 5(4), 9-17.

Ningrum, D. A., \& Suzan, L. (2015). Pengaruh Return on Equity (ROE), Pertumbuhan Penjualan, dan Earning Per Share (EPS) Terhadap Harga Saham (Studi pada Perusahaan Pertambangan Batubara yang Terdaftar di Bursa Efek Indonesia Periode 2010-2014). EProceedings of Management, 2(3).

OJK. (2020). Pasar Modal. Otoritas Jasa Keuangan.

https://www.ojk.go.id/id/kanal/pasarmodal/regulasi/undangundang/pages/undang-undang-nomor-8tahun-1995-tentang-pasar-modal.aspx

Polovina, N., \& Peasnell, K. (2015). The effect of foreign management and board membership on the performance of foreign acquired Turkish banks. International Journal of Managerial Finance.

Raharjanti, R., \& Setyowati, N. (2017). Pengaruh Struktur Kepemilikan dan Struktur Modal terhadap Harga Saham. Jurnal Akuntansi Dan Auditing, 14(2), 89-99.

Sekaran, U., \& Bougie, R. (2016). Research methods for business: A skill building approach. john wiley \& sons.

Sulistyastuti, D. R. (2002). Saham dan Obligasi: Ringkasan Teori dan Soal Jawab. Universitas Atmajaya Yogyakarta.

Widoatmojo, S. (2017). Pasar Modal Indonesia, Pengantar \& Studi Kasus. Ghalia Indonesia. 